\title{
STUDY FORMS OF FEMINISM IN SHORT STORY COLLECTION PARODIA BY ISTIFARI HASAN
}

\author{
Ahmad Asif Barkhoya ${ }^{1}$, Kamidjan ${ }^{2}$ \\ ${ }^{1,2}$ Pendidikan Bahasa dan Sastra Indonesia, Fakultas Ilmu Pendidikan, Universitas Hasyim Asy'ari
}

Corresponding Author: ${ }^{1} \underline{\text { aabarkhoya@gmail.com }}$

\begin{abstract}
The focus of this research actually lies on the descriptive qualitative research model with a socialfeminist approach. By using the object collection of Parodia short stories written by Istifari Hasan, researchers tried to show the forms of feminism contained therein. From sources that have been collected in parallel, researchers found that there are feminism forms contained in a collection of Parodia short stories by Istifari Hasan that are full of social values in real community life in socializing, especially for women. In this case, researchers also aim to cultivate the analysis of short stories in the area of Indonesian literature. With the short story analysis that carries the theme of feminism, it is hoped that readers or literary connoisseurs can get closer to understanding the meaning or message of the author. After the researcher found a form of feminism in a collection of Parodia short stories written by Istifari Hasan, the researcher tried to look back at the reality that occurred in the life of the surrounding community which was not much different from the events contained in literary works, especially short stories which are indeed often the object of social criticism for writers.
\end{abstract}

Keywords: feminism, short stories.

\section{KAJIAN BENTUK-BENTUK FEMINISME DALAM KUMPULAN CERPEN PARODIA KARYA ISTIFARI HASAN}

\begin{abstract}
Abstrak
Fokus pada penelitian ini sebenarnya terletak pada model penelitian deskriptif kualitatif dengan pendekatan sosialfeminis. Dengan menggunakan obyek kumpulan cerpen Parodia karya Istifari Hasan, peneliti berusaha menunjukkan bentuk-bentuk feminism yang terkandung didalamnya. Dari sumber yang telah dikumpulkan secara paralel, peneliti menemukan bahwasannya terdapat bentuk-bentuk feminism yang terkandung dalam kumpulan cerpen Parodia karya Istifari Hasan yang sarat akan nilai-nilai sosial dalam kehidupan masyarakat nyata dalam bersosialisasi, terutama bagi kaum perempuan. Dalam hal ini, peneliti juga bertujuan untuk membudayakan analisis karya cerpen diranah kesustraan Indonesia. Dengan adanya analisis cerpen yang yang mengangkat tema feminism, diharapakan pembaca ataupun penikmat sastra dapat lebih dekat dalam memahami makna atau pesan penulis. Setelah peneliti menemukan bentuk feminism dalam kumpulan cerpen Parodia karya Istifari Hasan peneliti mencoba melihat kembali realitas yang terjadi pada kehidupan masyarakat sekitar yang tidak jauh berbeda dengan kejadian yang terdapat di dalam karya sastra, terutama cerpen yang memang sering menjadi obyek kritik sosial bagi penulis.Kata Kunci: feminisme, cerpen.
\end{abstract}

\section{PENDAHULUAN}

Di era globalisasi ini, masih banyak perempuan yang mengalami diskriminasi dan diperlakukan tidak adil oleh laki-laki dalam budaya patriarki. Perempuan juga dipandang sebelah mata karena status sosial, terutama dari status sosial menengah ke bawah. Maka dari itu, feminisme memberikan paham tentang memperjuangkan hak-hak dan keadilan bagi perempuan yang terikat oleh struktur sosial dan budaya patriarki. Dengan kesadaran akan paham feminisme diharapkan, perempuan kembali mendapatkan hak-haknya dalam kehidupan masyarakat tanpa ada pihak yang dirugikan. 
Fenomena ketertindasan perempuan tidak hanya dijumpai dalam realitas sosial masyarakat. Hal ini juga digambarkan dengan jelas dalam karya sastra sebagai bentuk interpretasi pengarang atas kehidupan perempuan. Dalam karya sastra, pornografi dan kekerasan sering menempatkan perempuan sebagai korban. Karya sastra dipandang sebagai refleksi kehidupan berdasarkan sudut pandang pengarang terhadap realitas sosial masyarakat. Pengarang menuangkan setiap ide, gagasan, dan imajinasinya dalam mengolah fakta sosial menjadi sebuah tulisan yang indah dan menarik untuk dibaca dengan makna yang tersirat di dalamnya.

Cerpen merupakan salah satu karya sastra yang sering dijumpai dan merupakan salah satu karya sastra yang memiliki genre dalam bentuk prosa. Cerpen hadir sebagai medium untuk menggambarkan realitas sosial yang diolah secara kreatif oleh pengarang. Dalam menulis cerpen, pengarang biasanya menyesuaikan dengan kisah nyata yang terjadi daalam kehidupan sehari-hari, tapi dikemas dalam bentuk tulisan yang memiliki nilai keindahaan, sehingga menarik untuk dibaca.

Salah satu produk sastra yang mempresentasikan problematika feminisme dalam kehidupan masyarakat adalah Parodia, yang merupakan buku kumpulan cerpen karya Istifari Hasan yang terdiri dari delapan judul cerpen. Kehadiran seorang penulis perempuan di dunia sastra memang menjadikan kesastraan lebih berwarna. Seperti yang dilakukan oleh Istifari Hasan yang mengusung tema-tema tentang kesetaraan gender dan feminisme. Kumpulan cerpen Parodia karya Istifari Hasan ini akan peneliti gunakan sebagai objek penelitian. Dari kedelapan judul dalam kumpulan cerpen karya Istifari Hasan peneliti akan beruasaha menggambarkan feminisme yang terdapat didalam cerpen.

Dalam kumpulan cerpen ini Istifari mencoba menggambarkan bagaimana perlakuan ketidakadilan yang dialami oleh wanita pada kehidupan di masyarakat, khususnya pada masyarakat feodal. Kumpulan cerpen Parodia menarik untuk diteliti karena tema dalam cerpen mengungkapkan kejadian-kejadian jenaka yang banyak terjadi di kehidupan masyarakat dewasa ini. Seperti halnya, pernikahan padausia dini, perjodohan dan hak wanita dalam rumah tangga. Banyak sekali ketidaksetaraan hak antara wanita dan laki-laki di sekeliling kita dan Istifari mampu menggambarkannya dalam kumpulan cerpen Parodia.
Kumpulan cerpen ini akan dianalisis menggunakan pendekatan feminisme sastra. Gerakan feminisme cenderung memperjuangkan hak-hak dalam marginalisasi perempuan.Dengan lahirnya gerakan perempuan diharapkan, kedudukan perempuan menjadi lebih baik dari sebelumnya.

Alasan peneliti memilih untuk meneliti kajian feminism karena kajian feminism ini hendaknya mampu mengungkapkan ketidakadilan yang terjadi dalam kumpulan cerpen Parodia karya Istifari Hasan. Ketidakadilan tersebut terbagi menjadi empat, yaitu: 1) Marginalisasi; 2) subordinasi; 3)stereotip; dan 4) kekerasan. Adapun judul-judul cerpen yang akan dikaji oleh peneliti adalah Parodia, Dua Kendi Satu Hati, Mendayung Gelombang, dan Rere.

Berawal dari kesetaraan gender yang terjadi di lingkungan dewasa ini, peneliti berusaha mengungkapkan sisi feminis dari perempuan dalam kumpulan cerpen Parodia karya Istifari Hasan. Melalui penelitian ini, diharapkan bisa menjadi awal pembongkar tatanan sosial yang lebih baik bagi kaum perempuan dan laki-laki.Oleh karena itu, penelitian ini dirasa cukup penting untuk dikaji lebih luas agar kita bisa mengetahui lebih dalam sisi perempuan dari gambaran Istifari dalam kumpulan cerpen karyanya.

\section{METODOLOGI PENELITIAN}

Penelitian ini didesain sebagai penelitian kualitatif, yang mana hasil pembahasan dari penelitian berupaya menjelaskan atau mendeskripsikan secara rinci mengenai feminisme dalam kumpulan cerpen Parodia karya Istifari Hasan. Sebagaimana yang dikatakan oleh Bogdan dan Taylor (Iskandar, 2009: 11), bahwa metodologi kualitatif merupakan prosedur penelitian yang menghasilkan data deskriptif berupa kata-kata tertulis maupun lisan dari orangorang dan prilaku yang diamati.

Dengan menggunakan metode penelitian yang bersifat deskriptif kualitatif. Metode deskriptif dapat diuraikan sebagai prosedur pemcahan masalah yang diselidiki dengan menggambarkan keadaan objek penelitian pada saat sekarang berdasarkan fakta yang tampak atau sebagaimana adanya. Metode ini juga bertujuan untuk mendeskripsikan dan memahami adanya gambaraan feminisme yang terkandung dalam cerpen-cerpen karya Istifari Hasan.

Penelitian ini menggunakan metode penelitian kualitatif dengan beberapa pertimbangan: (1) penelitian ini bersifat penemuan dan dilakukan pada kondisi alamiah; 
(2) peneliti adalah instrumen kunci atau instrumen pertama yang melakukan pengamatan; (3) penelitian ini menggunakan kumpulan cerpen yang berupa data-data sebagai objek penelitian; (4) penelitian ini berhubungan dengan kehidupan sehari-hari. Sebagaiman yang dikatakan Iskandar (2009: 11), bahwa pendekatan kualitatif menekankan pada makna, penalaran, definisi suatu situasi tertentu, lebih banyak meneliti hal-hal yang berhubungan dengan kehidupan sehari-hari.

Sumber data dalam penelitian adalah objek dari mana data dapat diperoleh. Sedangkan yang dimaksud dengandata adalah segala keterangan (informasi) mengenai semua hal yang berkaitan dengan tujuan penelitian (Ahmad Tanzeh, 2011: 58).

Sebuah penelitian akan bisa dikatakan akurat jika terdapat sumber data. Oleh karena itu, sumber data pada penelitian ini adalah kumpulan cerpen yang berjudul Parodia karya Istifari Hasan, dengan tebal buku 111 (xiii + 111) halaman, satu jilid. Kumpulan cerpen ini diterbitkan pada tahun 2018 oleh penerbit Stelkendo Kreatif. Sampul depan maupun belakang berwarna coklat muda bercampur coklat tua di bagian bawah, dengan disertakan bentuk halilintar yang menyambar bumi. Dan di bagian tengah atas bertuliskan judul Parodia Kumpulan Cerpen, sedangkan di bagian bawah terdapat ilustrasi gambar perempuan membawa tongkat kupu-kupu yang identik dengan keindahan. Adapun judul-judul cerpen yang akan dikaji oleh peneliti adalah Parodia, Dua Kendi Satu Hati, Mendayung Gelombang, dan Rere.

Data berupa kata, frase, dan kalimat yang mengandung informasi tentang bentuk-bentuk dan nilai-nilai feminisme dalam cerpen-cerpen yang menjadi objek penelitian. Data dicatat dan diklasifikasikan sesuai dengan masalah yang diteliti. Disamping itu, juga dikumpulkan data yang berhubungan dengan informasi yang berkaitan dengan isu-isu feminisme dari berbagai sumber

Pengumpulan data pada penelitian ini adalah pustaka atau dokumen. Metode pustaka atau dokumen yaitu teknik pengumpulan data yang merupakan dokumen tertulis maupun lisan (Supratno dan Subandiyah, 2015: 16). Dokumen merupakan catatan peristiwa yang sudah berlalu. Dokumen bisa berbentuk tulisan, gambar, atau karya-karya monumental dari seseorang. Dokumen yang berbentuk tulisan misalnya catatan harian, sejarah kehidupan, ceritera, biografi, peraturan, kebijakan. Dokumen yang berbentuk gambar, misalnya foto, gambar hidup, sketsa, dan lain-lain.
Metode yang digunakan dalam penelitian ini adalah metode deskriptif, karena data di dalam penelitian ini berupa kata-kata, dan kalimat bukan berupa angka-angka sebagai hasil perhitungan statistik. Selain itu, laporan penelitian akan berisi kutipan-kutipan data untuk memberikan gambaran deskripsi laporan tersebut. Data itu berasal dari teks novel.Dengan demikian, metode deskriptif digunakan untuk mendeskripsikan keadaan objek yang diteliti dengan menguraikan hal-hal yang menjadi pusat perhatian yang mendukung objek penelitian. Sehingga penelitian ini akan menghasilkan data deskriptif yang kemudian data tersebut akan memberikan gambaran dan

Paparan yang dimaknai dan ditafsirkan oleh peneliti secara mendalam, sehingga peneliti akan melaporkan tentang bentuk penelitian. Bentuk penelitian ini adalah penelitian kualitatif, karena bentuk penelitian akan menghasilkan data dalam bentuk kata-kata maupun kalimat dan tidak dalam bentuk angkaangka ataupun mengadakan perhitungan. Adapun dalam penelitian ini menggunakan pendekatan kritik sastra feminisme, dengan kritik sastra feminis menunjukan bahwa pembaca perempuan membawa persepsi dan harapan ke dalam pengalaman sastranya (Showalter dalam Gamble, 2010).Menurut Goodman (dalam Sofia, 2009) mengatakan bahwa kritik sastra feminis merupakan sebuah pendekatan akademik pada studi sastra yang mengaplikasikan pemikiran feminis untuk menganalisis teks sastra dan konteks produksi dan resepsi.

Pengumpulan data dapat dilakukan dalam berbagai setting, berbagai sumber, dan berbagai cara. Bila dilihat dari setting-nya, data dapat dikumpulkan pada setting alamiah (natural setting), pada laboratorium dengan metode eksperimen, di sekolah dengan tenaga pendidikan dan kependidikan, di rumah dengan berbagai responden pada suatu seminar, diskusi, di jalan dan lain-lain. Bila dilihat dari sumber datanya, maka pengumpulan data dapat menggunakan sumber primer dan sekunder. Sumber primer adalah sumber data yang langsung memberikan data pada pengumpul data, dan sumber sekunder merupakan sumber yang tidak langsung memberikan data kepada pengumpul data, misalnya lewat orang lain atau lewat dokumen. Selanjutnya bila dilihat dari cara pengumpulan data, maka teknik pengumpulan data dilakukan dengan mencatat, mengumpulkan, memilah-milah, mengklasifikasikan, mengategorikan, mencari dan menemukan pola dan hubungan-hubungan yang 
ada dengan masalah penelitian, kemudian membuat temuan-temuan umum.

Teknik analisis data pada penelitian ini menggunakan teknikdeskriptif dan content analisys. Menurut Baylai dan Supratno (Supratno dan Subandiyah, 2015: 19) teknik analisis

\section{PEMBAHASAN}

1. Kajian Bentuk-bentuk Feminisme Dalam Kumpulan Cerpen Parodia Karya Istifari Hasan

Pada sub bab ini akan dipaparkan mengenai kajian feminisme yang terkadung dalam kumpulan Parodia karya Istifari Hasan. Kajian feminisme yang dilakukan berupaya untuk mengangkat derajat perempuan yang sering mengalami ketimpangan ataupun ketidakadilan gender. Adapun ketidakadilan tersebut berupa marginalisasi, subordinasi, stereotip, dan kekerasan.

Ketidakadilan gender yang berupa marginalisasi merupakan bentuk pengabaian hak-hak yang seharusnya didapatkan oleh pihak yang termarginalkan. Akan tetapi, hak tersebut diabaikan dengan berbagai alas an demi mencapai suatu tujuan. Dalam hal ini, perempuan lah yang paling sering menjadi pihak yang termarginalkan.Adapun ketidakadilan berupa marginalisasi yang terdapat dalam kumpulan cerpen Parodia karya Istifari Hasan digambarkan pada beberapa judul cerpennya, diantaranya yaitu terdapat dalam cerpen yang berjudul Parodia.

Dalam cerpen berjudul Parodia ketidak adilan berupa marginalisasi digambarkan dengan tindakan pengabaian hak-hak dari pihak yang termarginalkan, yaitu pihak perempuan.

"Kadang aku merasa apa yang terjadi dengan hidupku terjadi begitu saja tanpa kuminta dan bahkan aku tak pernah mengelak kemauan orang-orang terdekatku ketika menjodohkanku dengan lekaki yang sebenarnya tidak kucintai."

Pada kutipan di atas tokoh Aku mengalami ketidakadilan yang meminggirkan haknya atas segala sesuatu yang terjadi dalam hidupnya. Tokoh aku tidak mendapatkan hak untuk menolak dengan siapa tokoh Aku akan menikah. Dalam hal ini, tokoh Aku menjadi pihak yang termarginalkan, sebab dirinya harus menikah dengan orang yang tidak dicintainya. Hal ini deskriptif adalah suatu teknik analisis untuk mendeskripsikan makna data sehingga menimbulkan kejelasan dan mudah dipahami oleh pembaca. Teknik content analisys data adalah teknik analisis data yang lebih menekankan pada pengambilan makna data.

terjadi akibat ada pihak yang mengabaikan hak-hak yang dimiliki oleh tokoh Aku, yaitu orang-orang terdekatnya yang merasa lebih tahu apa yang terbaik bagi si tokoh Aku.

Dengan demikian, tokoh Aku hanya bisa pasrah dan tidak bisa menyampaikan haknya untuk menolak perjodohan tersebut.Pada akhirnya pernikahan yang tidak dikehendaki tokoh Aku itu berlangsung dan menyebabkan kehiudpannya menjadi tidak bahagia dan sangat merugikan dirinya.Sebab pada konteks ini, tokoh aku menekankan kembali bahwa pernikahan tersebut sangat tidak dikehendaki olehnya.

Adapun dalam cerpen yang berjudul Parodia ini, menceritakan mengenai kehidupan seorang pelacur bernama Yulia.Secara tidak langsung seorang pelacur juga mengalami ketidakadilan berupa marginalisasi, meskipun itu harus mengorbakan perasaannya sendiri, seperti yang tertera dalam kutipan sebagai berikut.

"Tapi bagaimana pun ini waktunya

aku mengorbankan perasaanku.

Aku harus tetap menatap kenyataan

bahwa aku benar-benar seorang

pelacur. Mereka membayarku

dengan uangnya. Karena itu aku tak berhak menolak."

Pada kutipan di atas tokoh Aku yang bernama Yulia harus mengabaikan perasaannya demi menjalani pekerjaannya sebagai seorang pelacur.Yulia mengalami ketidakadilan berupa marginalisasi oleh dirinya sendiri, meskipun itu adalah tuntutan pekerjaannya sebagai seorang pelacur.Yulia tidak berhak menolak tamu yang ingin melampiaskan nafsunya kepada Yulia, sebab mereka telah membayar Yulia dengan uang.

Pada dasarnya Yulia mengalami marginalisasi dari tamu-tamunya yang datang dengan menganggap bahwa Yulia hanya seorang pelacur yang dapat mereka nikmati hanya dengan membayar sejumlah uang.Oleh karena itu, Yulia tidak berhak untuk menolak mereka yang telah membayarnya dengan uang, 
Jurnal DISASTRI (Pendidikan Bahasa dan Sastra Indonesia)

Volume 3, Nomor 1, April 2021| P-ISSN : 2716-4114 | E-ISSN: 2722-3329

dari sini lah bentuk marginalisasi yang mengabaikan hak Yulia untuk menolak tamutamu yang datang dengan membawa sejumlah uang untuk dibayarkan kepada Yulia.Karena Yulia adalah seorang pelacur.

Selain dalam cerpen bejudul Parodiai bentuk ketidakadilan yang berupa marginalisasi juga terdapat dalam cepren yang berjudul Mendayung Gelombang.Dalam cerpen berjudul mendayung Gelombang banyak terdapat gambaran tentang marginalisasi, seperti yang dialami oleh tokoh Tija salah satu teman dari tokoh Aku yang terdapat dalam kutipan sebagai berikut.

"Tija?" desisku tiba-tiba menyebut nama teman sekelasku dulu. Entah bagaimana kini ia hidup bersama keluarganya. Yang kutahu, ia dipaksa menikah oleh kedua orang tuanya ketika selembar ijasah pelulusan SD belum ditangannya, dan semenjak kabar Tija akan dinikahkan aku jarang melihat Tija berangkat bersama dengan anakanak yang hendak mengaji sambil membawa obor."

Pada kutipan di atas menggambarkan kehidupan tokoh Tija yang dipaksa menikah oleh orang tuanya meskipun ijasah kelulusan SD belum diterima oleh Tija. Dalam hal ini, Tija mengalami ketidakadilan berupa marginalisasi yang sangat mencolok, terlihat sejak tokoh Tija hendak dinikahkan ia kehilangan haknya untuk berangkat mengaji ke surau setiap sore bersama teman-temannya.

Selain pasrah dan tidak dapat mengelak tokoh Tija benar-benar diabaikan haknya, bahkan sebelum Tija menerima ijasah kelulusan SD, dirinya sudah dipaksa menikah oleh orang tuanya.Dari sini, ketidakadilan yang dialami Tija menjadi penggambaran marginalisasi yang menganggap bahwa seorang gadis hanya berhak untuk urusan rumah tangga dan tidak berhak untuk menjalani pendidikan yang lebih tinggoi dibandingkan laki-laki yang lebih berhak dalam mendapatkan pendidikan tinggi guna mencari nafkah dan sebagai kepala rumah tangga.

Dalam cerpen berjudul Mendayung Gelombang bukan hanya tokoh Tija yang mengalam

ketidakadilan

berbentuk marginalisasi. Penggambaran yang menunjukkan bahwa marginalisasi sangat sering dialami oleh banyak perempuan lain. Ketidakadilan ini sangat tidak menguntungkan bagi pihak yang termarginalkan, khususnya perempuan.Hal ini juga terdapat dalam kutipan sebagai berikut.

"Kata orang-orang suaminya punya istri baru. Status Tija tidak jelas, sampai sekarang belum dicerai. Maryam juga begitu, satu bulan lalu suaminya baru pulang dari Jawa, membawa anak, katanya hasil dengan istrinya yang baru," lanjut Ibu."

Pada kutipan di atas menunjukkan bahwa bukan hanya tokoh Tija seorang yang mengalami ketidakadilan berupa marginalisasi.salah satu teman dari tokoh Aku yang lain juga mengalami hal yang serupa, yaitu tokoh Maryam. Dari sini terlihat bahwa tokoh Tija dan Maryam sebagai pihak yang termarginalkan kehilangan haknya sebagai seorang istri. Meskipun suami tokoh Tija sudah mempunyai istri baru, akan tetapi status tokoh Tija sebagai seorang istri tidak diperjelas oleh sang suami, apakah masih menjadi istrinya dalam artian masih berada dalam tanggung jawab suami atau sudah diceraikan dengan mencari istri baru tanpa seizing istrinya, Tija.

Begitu pun yang dialami oleh tokoh Maryam yang ditinggal suaminya merantau ke Jawa dan baru pulang dengan membawa seorang anak yang katanya dari hasil dengan istrinya yang baru.Di sini, tokoh Maryam juga kehilangan haknya sebagai seorang istri yang seharusnya berhak memberikan pertimbangan kepada suaminya ketika hendak menikah lagi.

Peristiwa di atas masih berlanjut dalam cerpen berjudul Mendayung Gelombang, selanjutnya tokoh Aku yang mengalami ketidakadilan berupa marginalisasi dari ibunya sendiri. Dalam hal ini, tokoh Aku kehilangan haknya bermain bersama teman-temannya yang lain. Akibatnya, tokoh Aku hanya dapat bersrah diri dan tak mampu mengelak kehendak ibunya, seperti yang tergambar dalam kutipan sebagai berikut.

"Ibu melarangku bermain dengan sembarang orang apalagi dengan laki-laki. Yang bisa kulakukan hanya 
Jurnal DISASTRI (Pendidikan Bahasa dan Sastra Indonesia)

Volume 3, Nomor 1, April 2021| P-ISSN : 2716-4114 | E-ISSN: 2722-3329

melihat dan mendengar apa yang

teman-temanku obrolin sepanjang

perjalanan menuju surau setiap

sore dari beranda ini."

Paragraf di atas menunjukkan bahwa tokoh Aku tidak bisa melakukan seperti yang teman-temannya lakukan.Yang bisa dilakukan hanyalah melihat dan mendengarkan obrolan teman-temannya yang hendak berangkat mengaji ke surau setiap sore dari beranda rumahnya. Ketidakadilan yang dialami oleh tokoh Aku berupa marginalisasi yang merenggut haknya untuk bergaul dengan orang lain, karena ibunya telah memberikan batasan kepada tokoh Aku. Sehingga, tokoh Aku merasa berbeda dengan teman-temannya.

Marginalisasi yang digambarkan kepada tokoh Aku dalam mengabaikan haknya untuk bermain dengan teman-temannya terlihat ketika tokoh Aku hanya bisa pasrah dan tak mampu melawan kehendak sang ibu. Selain kehilangan haknya untuk bermain bersama temantemannya, tokoh Aku juga tidak berhak untuk merasakan pengalaman seperti yang diobrolkan oleh teman-temannya, yaitu mengenal laki-laki.

Ketidakadilan yang berupa marginalisasi banyak tergambarkan dalam cerpen berjudul Mendayung Gelombangi.Dalam cerpen tersebut, seorang gadis hanya bisa pasrah kepada kehendak orang tua mereka tanpa menghiraukan hak-hak, cita-cita dan impian mereka.Hal tersebut digambarkan dalam kutipan sebagai berikut.

"Nasibku tak jauh berbeda dengan mereka: menikah muda dan cerai. Kami anak-anak desa dipaksa berserah kepada kehendak orang tua, mereka seperti tak mau tahu impian indah dan cita-cita anaknya. Kehidupan kami seperti sampan yang berayun-ayun di atas ombak pasang hingga tenggelam digiring gelombang."

Pada paragraf di atas menceritakan nasib tokoh Aku yang tak jauh berbeda dengan temantemannya yang juga mengalami ketidakadilan berupa marginalisasi.Selain kehilangan hak masa mudanya, tokoh Aku juga tidak mendapatkan haknya dalam mewujudkan impian indahnya dan mencapai cita-citanya.Paragraf di atas menggambarkan kehidupan para gadis di desanya tokoh Aku seperti sampan yang terombang-ambing di atas gelombang hingga akhirnya tenggelam dan hanyut digiring gelombang.

Selain mendapatkan perlakuan tidak adil dari orang tua mereka, tokoh Aku dan temanteman gadis yang satu desa dengannya juga mengalami ketidakadilan dari para suami yang dijodohkan paksa dengan mereka. Hal itu tergambar dalam kutipan sebagai berikut.

"Maryam," cerita Tija, "Ia sering

sakit sejak suaminya menikah lagi,

suaminya lebih banyak di rumah

istrinya yang kedua," imbuh Tija."

Berdasarkan kutipan di atas dapat dilihat bahwa Maryam juga mendapat perlakuan tidak adil dari suaminya yang sudah menikah lagi. Suami Maryam telah mengabaikan hak Maryam sebagai seorang istri yang seharusnya dijaga dan dirawat oleh suami, meskipun sang suami sudah memiliki istri baru bukan berarti Maryam tidak berhak mendapatkan perhatian darinya.

Dengan demikian, ketidakadilan berupa marginalisasi yang dialami oleh Maryam sangat merugikannya, sebab Maryam sangat membutuhkan perhatian dari sang suami dalam keadaan sakit, bukan justru lebih sering tinggal di rumah istri barunya.

Selain judul-judul cerpen yang sudah disebutkan, ketidakadilan berupa marginalisasi juga terdapat dalam cerpen yang berjudul Rere yang menggambarkan ketidakadilan terhadap tokoh Rere sendiri.Adapun kutipan yang menggambarkan persitiwa tersebut adalah sebagai berikut.

"Re, nanti malam ada tamu. Kami sekeluarga sudah berunding yang terbaik buat kamu. Sebelum kalian melakukan melakukan kesalahan semakin jauh, alangkah baiknya kalau kalian ditunangkan saja biar tidak menimbulkan fitnah. Ayahmu tak sanggup menanggung malu jika anak gadisnya yang di pesantern pacaran," ucap Paman Rere sesaat sebelum sampai dirumahnya." 
Jurnal DISASTRI (Pendidikan Bahasa dan Sastra Indonesia)

Volume 3, Nomor 1, April 2021| P-ISSN : 2716-4114 | E-ISSN: 2722-3329

Sesusai uraian kutipan di atas bahwa tokoh Rere kehilangan haknya dalam menyampaikan pendapatnya sebelum keputusan yang diambil oleh keluarganya ditetapkan.Sebab, dalam hal ini tokoh Rere mengalami ketidakadilan berupa marginalisasi yang mengakibatkan tokoh Rere menjadi pihak yang diabaikan haknya dengan suatu alasan untuk tujuan agar tidak terjadi kesalahan lebih lanjut.Padahal, tokoh Rere sebernarnya tidak melakukan kesalahan namun semua terjadi tenpa kehendaknya dan tidak dapat dihnidari.Hingga akhirnya, tokoh Rere harus menanggung kerugian yang sangat tidak diinginkan, yaitu menikah dengan orang yang tidak dicintainya.Hal ini pun terlihat dalam kutipan sebagai berikut.

"Rere tahu dirinya tak akan bisa melawan kehendak orang tuanya.

Sebenarnya keputusan orang tua

Rere menjemputnya ke pondok pesantren dan ingin menikahkannya dengan Faris, lelaki yang tak dicintainya, dipengaruhi oleh pamannya."

Pada kutipan di atas menunjukkan bahwa keputusan yang diambil oleh orang tua tokoh Rere telah mengabaikan hak yang dimiliki oleh tokoh Rere. Hal ini dipengaruhi oleh paman tokoh Rere yang juga telah mengabaikan hak tokoh Rere untuk menjelaskan apa yang terjadi antara tokoh Rere dengan tokoh Faris, lekaki yang akan dijodohkan dengannya meskipun tokoh Rere tidak mencintainya.

Dengan demikian, marginalisasi yang dialami oleh tokoh Rere merupan suatu bentuk ketidakadilan yang tidak diingnkannya. Namun, semua itu telah terjadi dan tokoh Rere telah kehiilangan haknya untuk menolak karena tindakan marginalisasi dari keluarganya yang beranggapan bahwa tokoh Rere merupakan sumber kesalahan dari apa yang terjadi. Dalam hal ini, terlihat jelas bahwa tindakan memarginalkan sangat merugikan bagi pihak yang termarginalkan.

Subordinasi atau penomorduaan merupakan bentuk ketidakadilan gender yang beranggapan bahwa peremmpuan lebih rendah disbanding laki-laki dalam hal produksi. Perempuan dianggap hanya bertanggung jawab dan memiliki peran dalam urusan domestik dan reproduksi, sementara laki-laki dalam urusan public atau produksi.

Adapun bentuk-bentuk subordinasi yang terdapat dalam kumpulan cerpen Parodia karya Istifari Hasan diantaranya terdapat dalam cerpen berjudul Parodia yang dapat dilihat dalam kutipan sebagai berikut.

"Suamiku selalu pulang ketika hari menjelang pagi, ia tak peduli ketika aku menyambutnya dengan uraian air mata, ia tak pernah menjawab pertanyaan-pertanyaanku bahkan berulangkali membuang makanan dan minuman yang kusajikan"

Dari kutipan di atas dapat dipahami bahwa tokoh Aku sebagai seorang istri hanya bertanggung jawab dalam urusan rumah tangga dan tidak berhak untuk mengetahui urusan sang suami yang memiliki peran produksi. Dalam hal ini, jelas bahwa sang suami menganggap rendah tokoh Aku sebagai seorang istri sehingga ia tidak menghiraukan dengan apa yang terjadi terhadap tokoh Aku. Bahkan suami dari tokoh Aku sampai melakukan tindakan kasar dengan membuang makan dan minuman yang disajikan oleh istrinya.

Ketidakadilan dalam bentuk stereotip merupakan pemberian citra sebagai tolak ukur terhadap seseorang berdasarkan suatu anggapan yang tidak akurat. Dalam hal ini, perempuan sering mendapatkan pelabelan negatif yang beranggapan bahwa perempuan lah yang menjadi sumber kesalahan.

Peristiwa yang menggambarkan stereotip sebagai bentuk ketidakadilan gender yang terkandung dalam kumpulan cerpen Parodia karya Istifari Hasan terdapat dalam cerpen dengan judul Parodia. Adapun kutipan yang menunjukkan peristiwa tersebut adalah sebagai berikut.

"Ketika tiba-tiba ibu mertuaku menyalahkan bahwa suamiku jarang pulang karena aku tak bisa menjadi istri yang baik, dengan tak bisa tak bisa melayaninya dengan baik sehingga suaimku mencari pelampiasan di luar rumah."

Kutipan di atas menggambarkan tokoh Aku sebagai seorang istri menjadi sumber masalah yang menyebabkan suaminya mencari 
Jurnal DISASTRI (Pendidikan Bahasa dan Sastra Indonesia)

\section{Volume 3, Nomor 1, April 2021| P-ISSN : 2716-4114 | E-ISSN: 2722-3329}

pelampiasan di luar rumah akibat tokoh Aku tidak mampu melayani suaminya sebagai seorang istri. Padahal sebenarnya tokoh Aku sudah melakukan perannya sebagai seorang istri, namun sang suami tetap tidak menghargai yang dilakukan istrinya.

Berdasarkan kutipan di atas, dapat dilihat bahwa tokoh Aku mendapatkan tolak ukur yang didasarkan suatu anggapan yang salah, sehingga ketidakadilan berupa stereotip dialami oleh tokoh Aku. Dari pelabelan yang diberikan oleh ibu mertuanya, tokoh Aku dianggap sebagai penyebab suaminya yang merasa tidak puas dengan pelayanan dari tokoh Aku sebagai istri, hingga akhrnya sang suami melampiaskan ketidakpuasannya di luar rumah dengan wanita lain.

Ketidakadilan gender berupa kekerasan merupakan semua tindakan membahayakan yang dilakukan di luar kehendak orang tersebut yang didasarkan atas perbedaan peran laki-laki dan perempuan. Kekerasan tersebut diarahkan pada orang atas dasar jenis kelamin atau seks.Adapun kekerasan terhadap perempuan adalah segala bentuk kekerasan yang berdampak pada fisik, psikis dan seksual atau membawa penderitaan bagi perempuan termasuk di dalamnya segala bentuk tindakan, paksaan, kesewenangwenangan serta merampas kemerdekaan, yang dilakukan di ranah publik maupun kehidupan pribadi.

Pada kumpulan cerpen Parodia karya Istifari Hasan terdapat beberapa gambaran mengenai kekerasan terhadap perempuan, diantaranya dalam cerpen berjudul Parodia.Adapun kutipan yang menggambarkan peristiwa tersebut adalah sebagai berikut.

"Suamiku selalu pulang ketika hari menjelang pagi, ia tak peduli ketika aku menyambutnya dengan uraian air mata, ia tak pernah menjawab pertanyaan-pertanyaanku bahkan berulangkali membuang makanan dan minuman yang kusajikan."

Dari kutipan di atas menggambarkan bagaimana bentuk kekerasan yang dialami oleh tokoh Aku, yaitu makanan yang disajikan kepada suaminya berulangkali dibuang dan tidak mendapatkan penghargaan sedikit pun. Tokoh Aku sebagai seorang istri secara tidak langsung mengalami kekerasan psikis, dari tindakan sang suami yang tidak menghargai makanan dan minuman yang disajikan oleh tokoh Aku, terlebih sang suami membuang segala yang disajikan kepadanya. Dari sini dapat dilihat bahwa mental tokoh Aku mengalami tekanan dan kekerasan secara batin.

Dalam hal ini, tokoh Aku tidak dapat berbuat banyak sebagai seorang istri yang dianggap lemah dan tidak berguna bagi sang suami.

\section{Feminisme dalam Kumpulan Cerpen Parodia Karya Istifari Hasan}

Seperti yang kita ketahui bahwa gerakan feminisme merupakan sebuah gerakan perempuan yang menuntut emansipasi atau kesamaan dan keadilan hak dengan lakilaki.Dalam suatu tindakan pastinya tidak jauh dari pro dan kontra.Dalam gerakan feminisme ini juga memiliki pro dan kontra yang terjadi di masyarakat. Tentunya, setiap perempuan di seluruh dunia pro dengan gerakan feminisme ini, alasan secara umum mereka pro dalam gerakan ini adalah hak perempuan yang disetarakan dengan hak-hak laki-laki, agar tidak adak lagi ketertindasan dan ketidakadilan.

Sebagian kaum feminisme berpendapat bahwa laki-laki dapat menyatakan dri mereka feminis sepanjang mereka ikut berjuang bagi kepentingan perempuan.Oleh karena itu, siapapun yang ikut berjuang melawan penindasan terhadap perempuan lebih tepat dikatakan sebagai kelompok profeminisme.

Adapun bentuk-bentuk gerakan profeminisme yang terkandung dalam kumpulan cerpen Parodia karya Istifari Hasan, diantaranya terdapat dalam cerpen dengan judul Parodia. Berikut kutipan yang menunjukkan bentuk gerakan profeminisme tersebut.

(1) "Sebagai pelacur, sepenuhnya aku sadar bahwa aku tak boleh memberikan segalanya kepada laki-laki yang ingin menikmati tubuhku. Mereka harus enyah seusai melampiaskan birahinya."

Pada kutipan diatas menunjukkan bagaimana tokoh Aku yang ingin menjaga kehormatan seorang perempuan, meskipun dirinya adalah pelacur. Sebagai seorang pelacur, tokoh Aku tidak ingin memberikan segala yang 
Jurnal DISASTRI (Pendidikan Bahasa dan Sastra Indonesia)

Volume 3, Nomor 1, April 2021| P-ISSN : 2716-4114 | E-ISSN: 2722-3329

dimilikinya kepada tamu-tamu yang datang, hal ini menunjukkan sikap profesionalnya sebagai seorang pelacur. Dari sini dapat dikatakan bahwa tokoh Aku berusaha melakukan tindakan agar dirinya sebagai perempuan lebih dihargai meskipun sebagai seorang pelacur.

Kontra feminis adalah Sebuah bentuk deskontruksi, ketika istilah profeminis, berarti akan ada paradoksal yang menyatakan kebalikan dalam hal ini biasa disebut kontra feminis. Hal ini merupakan bentuk dari oposisi biner.Kontra feminis merupkan kebalikan dari profeminis, jika profeminis mempunyai sifat menghargai terhadap perempuan, maka kontra feminis adalah sifat yang menentang perempuan.

Adapun bentuk gerakan kontra feminis yang terkandung dalam kumpulan cerpen Parodia karya Istifari Hasan, diantaranya terdapat dalan cerpen berjudul Parodia. Kutipan yang menunjukkan adanya gerakan kontra feminis tersebut adalah sebagai berikut.

"Apa maksudmu, Surya? Aku seorang pelacur. Dibayar ketika selesai ditiduri."

Pada kutipan di atas menunjukkan bahwa tokoh Aku beranggapan dirinya hanyalah seorang pelacur yang ditiduri kemudian dibayar. Hal ini menunjukkan bagaimana harga diri seorang perempuan sebagai pelacur memang untuk dibayar dan ditiduri. Padahal perempuan tidak seharusnya menjual kehormatannya demi uang. Dari sini dapat dikatakan bahwa kutipan di atas merupakan salah satu tindakan kontra feminis, meskipun secara moral.

Peristiwa lain dalam cerpen Parodia yang menggambarkan tindakan kontra feminis adalah sebagai berikut.

"Usiaku masih belasan tahun ketika pernikahan kami dilangsungkan, pernikahan yang, sekali lagi, tak pernah kukehendaki. Tapi aku tak pernah bisa mengelak kehendak orang tua yang, seakan lebih tahu apa yang terbaik menurut anaknya."

Peristiwa di atas menggambarkan bagaimana keadaan tokoh Aku yang dipaksa oleh orang tuanya untuk menikah di usia dini. Pemaksaan tersebut menjadikan tokoh Aku sebagai perempuan yang menderita dan mengalami ketidakadilan. Hal ini menunjukkan bahwa pemaksaan yang dilakukan oleh orang tua dari tokoh Aku, yang beranggapan mereka lebih tahu apa yang terbaik untuk anaknya merupakan suatu tindakan yang kontra feminis. Sebab, anggapan yang mengabaikan hak dari pihak yang terabaikan haknya tersebut merupakan bentuk dari ketidakadilan gender.

\section{SIMPULAN}

Kumpulan cerpen Parodia merupakan karya Istifari Hasan yang terbit pada tahun 2018. Dalam cerpen-cerpen karya Istifari Hasan terdapat beberapa cerpen yang mengandung kajian feminism. Penelitian ini menjabarkan bentuk ketidakadilan gender dan bentuk-bentuk gerakan profenimisme dan kontra feminis yang terdapat dalam kumpulan cerpen Parodia karya Istifari Hasan.

Hasil analisis kajian feminism dalam kumpulan cerpen Parodia karya Istifari Hasan dibagi menjadi dua, yaitu bentuk ketidakadilan gender dan bentuk feminism. Adapun hasil analisis tersebut dapat disimpulkan sebagai berikut :

\section{Bentuk Ketidakadilan Gender}

Bentuk-bentuk ketidakadilan gender yang terdapat dalam kumpulan cerpen Parodia yaitu berupa marginalisasi, subordinasi, stereotip, dan kekerasan. Bentuk ketidakadilan yang berupa magninalisasi terdapat dalam beberapa judul cerpen karya Istifari Hasan. Cerpen-cerpen yang mengandung bentuk ketidakadilan berupa marginalisasi tersebut adalah Parodia, Mendayung Gelombang, dan Rere.

Adapun bentuk ketidakadilan yang berupa subornasi terdapat pada cerpen Parodia dan Mendayung Gelombang. Ketidakadilan berupa subornasi merupakan bentuk ketidakadilan yang menganggap bahwa perempuan lebih redah dari pada laki-laki, dan adanya anggapann bahwa perempuan hanya bertanggung jawab pada urusan domestic, sedangkan untuk urusan publik adalah peran laki-laki.

Stereotip merupakan bentuk ketidakadilan gender yang memberikann citra buruk kepada perempuan sebagai tolak ukur yang didasarkan pada suatu anggapan yang salah. Stereotip, menganggap perempuan sebagai sumber kesalahan. Cerpen-cerpen dari kumpulan cerpen Parodia yang menggandung bentuk ketidakadilan berupa stereotip adalah Parodia, Mendayung Gelombang, dan Rere.

Cerpen-cerpen dengan judul Parodia, Dua Kendi Satu Cinta, Mendayung Gelombang, dan Rere merupakan cerpen-cerpen yang menggambarkan bentuk ketidakadilan gender berupa kekerasa. Kekerasan yang dilakukan dapat berupa serangan fisik ataupun psikologis. 
Jurnal DISASTRI (Pendidikan Bahasa dan Sastra Indonesia)

Volume 3, Nomor 1, April 2021| P-ISSN : 2716-4114 | E-ISSN: 2722-3329

2. Bentuk-bentuk Feminisme

Sebagian kaum feminsme berpendapat bahwa laki-laki dapat menyatakan diri mereka feminis sepanjang mereka ikut berjuan bagi kepentingan perempuan. Sekolompok feminis lain beranggapan bahwa laki-laki tidak dapat menjadi feminis karena tidak mengalami diskriminasi dan penindasan sebagaimana dialami kaum perempuan. Oleh karena itu, siapapun yang ikut berjuan melawan penndasan terhadap perempuan lebih tepat dikatakan sebagi kelompok profenisme. Adapun kontra feminis adalah sebuah bentuk deskontruksi, ketika istilah profeminis, berarti akan ada paradoksal yang menyatakan kebalikan dalam hal hal ini bisa disebut kontra feminis. Hal ini merupakan bentuk dari oposisi biner. Kontra feminis merupakan kebalikan dari profeminis, jika profeminis mempunyai sifat menghargai kepada perempuan, maka kontra feminis adalah sifat yang menentang perempuan.

Adapun cerpen-cerpen yang menunjukkan adanya gerakan-gerakan profenisme adalah Parodia, Mendayung Gelombang, dan Rere. Sedangkan gerakan kontra feminis digambarkan didalam cerpen-cerpen dengan judul Parodia, Mendayung Gelombang, dan Rere.

\section{DAFTAR PUSTAKA}

Djoko Pradopo, Rachmat. 2011. Beberapa Teori Sastra, Metode Kritik,dan Penerapannya. Yogyakarta: Pustaka Pelajar.

Endraswara, Suwardi. 2013. Metodologi Penelitian Sastra. Yogyakarta: CAPS (Center for Academic Publishing Service).

Endraswara, Suwardi. 2013. Teori Kritik Sastra. Yogyakarta: CAPS (Center for Academic Publishing Service).

Ghony, Djunaidi dan Faozan Almanshur. 2016. Metode penelitian kualitatif. Jogjakarta: ArRuzz Media.

Hasan, Istifari. 2018. Kumpulan Cerpen: Parodia. Yogyakarta: Stelkendo Kreatif.

Iskandar. 2009. Metodologi Penelitian Kualitatif. Jakarta: Gaung Persada (GP Press).

Kutha Ratna, Nyoman. 2004. Teori, Metode, dan Teknik Penelitian Sastra. Yogyakarta: Pustaka Pelajar.

Priyatni, Endah Tri. 2010. Membaca Sastra dengan Ancangan Literasi Kritis. Jakarta: Bumi Aksara.
Rohman, Saifur dan Emzir. 2016. Teori dan Pengajaran Sastra. Jakarta: Rajawali Pers.

Rokhmansyah, Alfian. 2014. Studi dan Pengkajian Sastra. Yogyakarta: Graha Ilmu.

Rosyid, Tony. 2011. Anak Halilintar. Tangerang: Jelajah Nusa.

Sugiyono. 2015. Metode Penelitian Pendidikan: pendekatan kuantitatif, kualitatif dan $R \& D$. Bandung: Alfabeta.

Sugihastuti dan Itsna Hadi Septiawan. 2007. Gender dan Inferioritas Perempuan: Praktik kritik Sastra Feminis. Yogyakarta: Pustaka Pelajar.

Sugihastuti dan Suharto. 2002. Kritik Sastra Feminis: Teori dan Aplikasinya. Yogyakarta: Pustaka Pelajar.

Supratno, Haris dan Heny Subandiyah. 2015. Folklor Setengah Lisan Sebagai Media Pendidikan Karakter Mahasiswa. Surabaya: Unesa University Pers.

Teeuw, A. 1984. Sastra dan Ilmu Sastra. Bandung: Pustaka Jaya.

Wellek, Rene dan Austin Warren. 2014. Teori Kesustraan. Terjemahan Melani Budianti. Jakarta: PT Gramedia. 